\title{
CREDIT-WORThiness PREDICTION In ENERGy-SAVING FINANCE USING MACHINE LEARNING MODEL
}

\author{
Eka Sudarmaji*
}

Department Doctoral Student

IPB University \& University of Pancasila, Jakarta

Indonesia

esudarmaji@univpancasila.ac.id

Noer Azam Achsani

Department School of Business

IPB University, Bogor

Indonesia

achsani@yahoo.com

\section{Yandra Arkeman}

Department Program Studi Teknologi Industri Pertanian

IPB University, Bogor

Indonesia

yandra.arkeman@gmail.com

\section{Idqan Fahmi}

Department School of Business

IPB University, Bogor

Indonesia

ifahmi@mb.ipb.ac.id

*Corresponding Author email: esudarmaji@univpancasila.ac.id 


\section{A B S T R A C T}

Companies can form their own "ESCO model" with their capitals. New opportunities that Energy Saving Company (ESCO) can do was to offer PSS business model in the form of Energy Saving Agreement (ESA) or Energy Saving Performance Contract (ESPC), which was known as "saving back arrangement financing." ESCO contracts could free business owners from new upfront investment. Unfortunately, customer's creditworthiness was becoming more crucial for ESCO. Machine learning was used to predict the creditworthiness of clients in ESCO financing processes. This research aimed to develop a scoring model to leverage a machine learning and life cycle cost analysis (LCCA) to evaluate alternative financing for Energy Saving in Indonesia. Research from the case studies leads to a clearer understanding of the factors that affect all parties' decisions to implement and continue with their ESCO project. Both considerations, technology, and administration emerge from this case study which greatly influenced the participants to adopt the decision and continue with the ESCO project. In contrast, both parties agreed to solve the credit risk constraints on the project. This study indicates that administration influences were more significant than the technological factor in shaping their decisions.

Keywords: LCCA, Machine Learning, ESCO, Creditworthiness

\section{R E S E A R C H H I G H L I G T S}

This study explored the impact of an energy-efficiency lighting program on one of the ways of reducing energy usage was by switching to energy-saving lightings. The use of energy-saving equipment reduces energy costs (Almeida, Santos, Paolo, \& Quicheron, 2014; Bennich, 2015; Polzin, von Flotow, \& Nolden, 2016). Despite the numerous opportunities, retrofitting remains an exception; the energy efficiency potential in Indonesia was immense. Life cycle cost (LCC) was one way of calculating the overall cost of ownership. LCC may be used as an investment strategy that measures a company's entire cost of owning, managing, sustaining, and disposing of an asset (Fuller \& Petersen, 1996). In addition to the cost of credit default risks, the retrofitting aspects' cost was a critical factor. The authors investigate which factors, as an ESCO, approved the final retrofitting project chosen. The authors used Machine Learning $(\mathrm{ML})$ to predict the probability of future actions. 


\section{G R A P H I C A L A B S T R A C T}

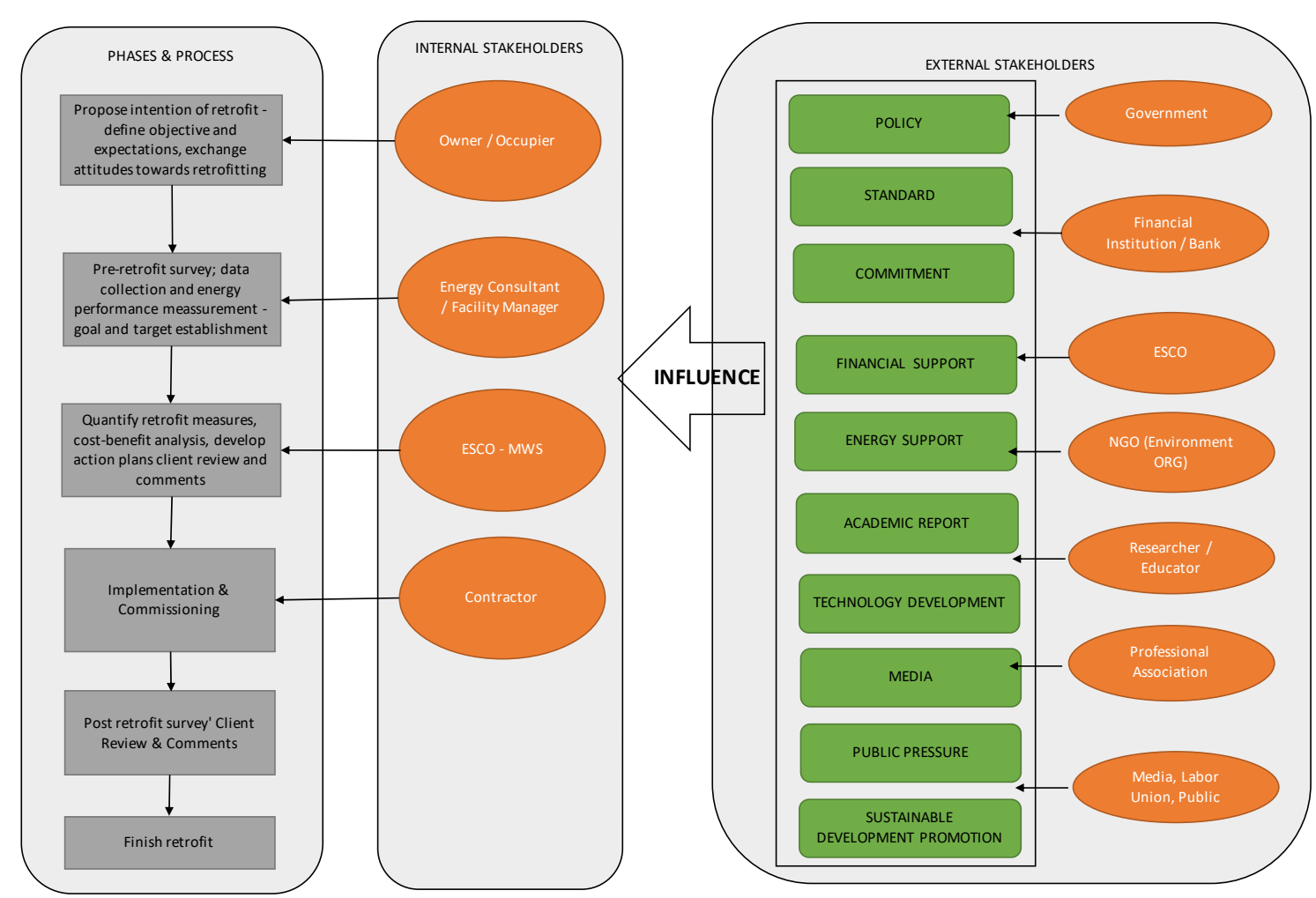

Fig. 1. Retrofitting Steps (modified from X. Liang, Peng, \& Shen, 2016)

\section{Research Objectives}

Our research aims to build a credit risk modeling framework that will reduce the risk of credit given to retrofitting projects while growing ESCO benefits. As a result, this research aimed to find the best modeling with the best performance and accuracy. This paper endeavors to show how ESCO can help customers tackle energy efficiency projects with a real case study. The ESCO provider was 'MWS,' and the customer was SHJ. The authors referred to use a pseudonymous name for this study. This study focuses on MWS that adopted the retrofitting practices with their own "ESCO model" on energy management or conservative energy projects or activities. MWS was intended to introduce the latest PSS model in their own "ESCO model" with their capitals in Indonesia. To finance the retrofitting project, MWS performed a simple financial analysis to determine the value, risk, and liquidity effect of suitable projects. To perform successfully, energy efficiency projects need to be regarded on the same par as others. The MWS uses finance analysis to assess whether an investment results in a good return while not damaging the consumer base.

\section{Methodology}

This paper endeavors to show how ESCO can help customers tackle energy efficiency projects with a real case study. The ESCO provider was 'MWS,' and the customer was SHJ. 
The authors referred to use a pseudonymous name for this study. This study focuses on MWS that adopted the retrofitting practices with their own "ESCO model" on energy management or conservative energy projects or activities. MWS was intended to introduce the latest PSS model in their own "ESCO model" with their capitals in Indonesia. To finance the retrofitting project, MWS performed a simple financial analysis to determine the value, risk, and liquidity effect of suitable projects. To perform successfully, energy efficiency projects need to be regarded on the same par as others. The MWS uses finance analysis to assess whether an investment results in a good return while not damaging the consumer base. The interviewing process gathers information directly from the company's director, chief leaders, and general managers involved in the retrofitting process. This phase helps the authors recognize the industry's most critical aspects, including technological and managerial aspects. Interviews lasted anywhere from twenty minutes to sixty minutes and were performed between November 2019 and January 2020.

\section{Results}

This model's p-value was 1,852 x 10^-187 which less than 0.01 or $1 \%$ as was thought 'very good.' The $\mathrm{p}=$ value of each variable as a list under $\mathrm{P}>|\mathrm{z}|$ was less than 0.01 or $1 \%$. Pseudo RSquared was 0.4810 or $48.19 \%$. From the pseudo R-Square value, it was obtained that the influence of all independent variables on dependent variables (retrofitting project) was 48.19\%. Obtained multinomial logistics regression model for log category ratio retrofitting project $=1$ (Take) and retrofitting project $=0$ (Hold and Reject) was $-6.5619+-4.0780$ (Project Agreement) + 0.5237 (Upfront Investment ) + 2.0639 (Revenue Factors) + 0.4995 (Additional Revenue Factors) + 0.5579 (Investment Return) + 1.3236 (Customer) - 0.7805 (Type of Customer).

\section{Findings}

The misclassification rate of this model can be computed as: Accuracy Rate $=\mathrm{FP}+\mathrm{FN} /$ $(\mathrm{TP}+\mathrm{TN}+\mathrm{FP}+\mathrm{FN})=473+43 /(28+40)=88.3562 \%$. The results of calculations using multinomial logistic regression showed that the accuracy value of prediction data with test data was $88.3562 \%$. A common practice was to use the Receiver Operating Characteristics $(\mathrm{ROC})$ curve, which plots the false positive rate (FPR) on the $\mathrm{Y}$-axis against the true positive rate (TPR) on the X-axis, for a range of threshold values (usually percentile values). Prediction rate result that refers to the percentage of correct predictions among all test data, were as follows: Prediction Rate $=473 /(473+43)=91.67 \%$, False Positive Rate $(F P R)=$ $28 /(28+43)=39.44 \%$ and True Positive Rate, it called as Recall or 'Sensitivity Rate' as it was defined as number of positive cases that were correctly identified (TPR) was 473/(473+40) $=92.20 \%$.

\section{References}

Almeida, A. De, Santos, B., Paolo, B., \& Quicheron, M. (2014). Solid-state lighting review Potential and challenges in Europe. Renewable and Sustainable Energy Reviews, 34, 30-48. 
Bennich, P. (2015). Test Report - Clear, Non-Directional LED Lamps.

Fuller, S. K., \& Petersen, S. R. (1996). LCCosting Manual for the Federal Energy Management Program. NIST Handbook 135.

Liang, X., Peng, Y., \& Shen, G. Q. (2016). Theory-based game analysis of decision-making for green retrofit under different occupancy types. Journal of Cleaner Production, 137, $1300-1312$.

Polzin, F., von Flotow, P., \& Nolden, C. (2016). Modes of governance for municipal energy efficiency services - The case of LED street lighting in Germany. Journal of Cleaner Production, 139, 133-145. 